\title{
Design and Realization of a UV-C Based Disinfection Tools Monitored by Mobile Application
}

\section{Baba Ngom*, Mouhamadou Thiam, Mame Faty Mbaye, Moussa Sow, Khadim Hann, Mamadou Wade}

Laboratoire Sciences et Techniques de l'Eau et de l'Environnement (LASTEE), Ecole Polytechnique de Thiès (EPT), Thiès, Sénégal Email: *bngom@ept.sn

How to cite this paper: Ngom, B., Thiam, M., Mbaye, M.F., Sow, M., Hann, K. and Wade, M. (2022) Design and Realization of a UV-C Based Disinfection Tools Monitored by Mobile Application. Open Journal of Applied Sciences, 12, 155-163. https://doi.org/10.4236/ojapps.2022.121011

Received: January 5, 2022

Accepted: January 27, 2022

Published: January 30, 2022

Copyright $\odot 2022$ by author(s) and Scientific Research Publishing Inc. This work is licensed under the Creative Commons Attribution International License (CC BY 4.0).

http://creativecommons.org/licenses/by/4.0/ (c) (i) Open Access

\begin{abstract}
In many outbreaks, patients and healthcare workers are particularly at risk from nosocomial infections as a result of non-effective disinfection methods. With increasing incidence of viral infections such as severe acute respiratory syndrome, in one hand, and the increase in the rate of antibiotic resistant bacteria associated with nosocomial infections in other hand, there is a need to design novel engineering tools for inactivation of nosocomial pathogens. Ultraviolet germicidal irradiation (UVGI) is considered as a promising method to inactivate bacteria and viruses. This paper presents UV-C Based disinfection tools monitored by mobile application, designed for hospital and Epidemic Treatment Center. The evolution of the irradiation intensity over time was evaluated, and the theorical disinfection duration for several nosocomial pathogens was determined. In the case of SARS-CoV2, less than 12 minutes were needed to achieve $99.99 \%$ viral reduction in a room of $36 \mathrm{sqm}$.
\end{abstract}

\section{Keywords}

Disinfection, UVGI, SARS-CoV2, Nosocomial Infections

\section{Introduction}

Nosocomial infections, or "healthcare-associated infections", are infections contracted in health facilities such as a hospital or clinic. In these hospital settings, controlling these nosocomial infections is a daily struggle. At any given time, according to the World Health Organization (WHO), more than 1.4 million people worldwide suffer from complications acquired in hospital [1].

In Senegal, with the establishment of a program to fight against nosocomial 
infections (PRONALIN) since 2004, many studies have been initiated in order to better analyze the situation and assess the effectiveness of activities to fight against nosocomial infections. A survey carried out in 2007 in fifteen (15) regional hospitals found a rate of these infections of $4.8 \%$. It was $10.9 \%$ at the national university hospital (CHNU) of Fann which has the biggest epidemic treatment center [2].

To this hard-daily battle that hospitals and healthcare professionals are facing, there has recently been added another tougher enemy: the COVID-19 [3] [4]. Indeed, on March 2, 2020, Senegal declared its first case of corona virus, and since that day, more than 75,000 cases have been reported [5].

The possible main route of transmission is thought to be the close contact and respiratory droplets. Other routes of transmission are through contaminated surfaces as well as airborne transmission [6]. Therefore, to break the transmission chain, healthcare professionals perform either traditional cleaning and/or chemical disinfection of surfaces in the hospital environment using products such as chlorine, alcohol, etc. However, it is clear that traditional cleaning alone is not enough, because studies have shown that more than $50 \%$ of surfaces were still infected even after the best manual cleaning [1]. In addition, disinfection with chemicals has adverse effects on public health and medical equipment [7].

It has therefore become urgent to think of an effective, environment friendly and non-corrosive disinfection method. In this paper we proposed a mobile automated UV-C device controlled by a mobile application and intended for hospital room-decontamination.

A lot of work has been done on UV-C and their use in disinfection of hospital room, however most of the designed UVGI lack of security, the users may be exposed to the UV-C irradiation, known to be very dangerous for public health. By allowing distance monitoring, this work represents a huge contribution to UVGI technology development, and healthcare professional protection strategies and politics.

Dose of UV-C emitted by the device is not necessarily the same as the dose received in an area, as has been highlighted in some studies [8] [9]. Furthermore, its relatively short wavelength makes it most efficient only over short distances and in a direct line with the light source. The UV-C dose received in different areas of the room would therefore need to be measured to ensure that an adequate dose has been reached. In this study an electronic and spectral radiometer was used to assess UV-C irradiance in different area of the room.

This work gave insight into the use of UVGI technology to fight nosocomial infections. It provided also a solid basis for future works aimed to develop novel engineering tools for healthcare environment disinfection.

\section{Materials and Methods}

\subsection{Irradiance Measurements}

The irradiance measurements were conducted with UV-C radiometer (LS126-C, Linshang, China). This UV light meter is specially designed for $253.7 \mathrm{~nm} \mathrm{UV}$ 
germicidal lamps (low-pressure mercury lamps). It is equiped with bluetooth that allows real-time data collection through a mobile phone application. Table 1 shows the characteristics of the radiometer.

The experimental measurements are made under conditions similar to those of use, in other words the experimental area will not be isolated (see Figure 1).

To make the measurements, the radiometer is placed in different positions from the device. For example, if we are 1 meter from the device on the horizontal plane, different measurements are taken by moving the radiometer on the vertical plane (see Figure 2).

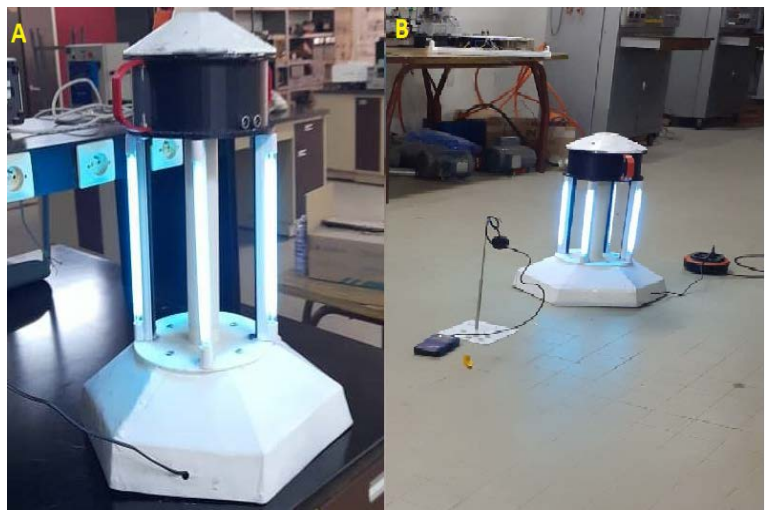

Figure 1. UVGI. A: Automated UV-C device photo; B: irradiation intensity measurements set up.

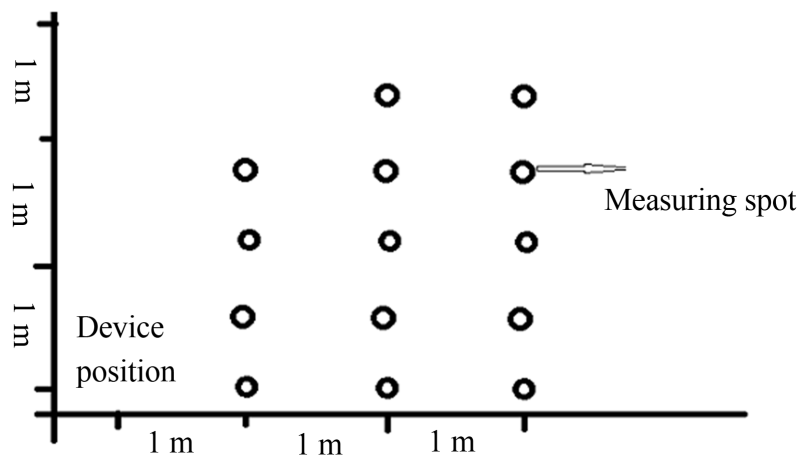

Figure 2. Irradiance measurement design.

Table 1. Radiometer technical characteristics.

\begin{tabular}{cc}
\hline Brand name & LS126C \\
\hline Spectral response & $230 \mathrm{~nm}-280 \mathrm{~nm}, \lambda \mathrm{p}=254 \mathrm{~nm}$ \\
Measuring range & $0-20,000 \mu \mathrm{W} / \mathrm{cm}^{2}$ \\
Resolution & $0.1 \mu \mathrm{W} / \mathrm{cm}^{2}$ \\
Measuring accuracy & $\pm 10 \%$ \\
Power data storage interval & $1 \mathrm{~s} / 10 \mathrm{~s} / 60 \mathrm{~s}$ optional \\
Recording period & $10 \mathrm{~min} / 100 \mathrm{~min} / 600 \mathrm{~min}$ \\
Bluetooth transmission distance & $50 \mathrm{~meters}($ open area)
\end{tabular}




\subsection{UV-C Device Design}

The UV-C device is made of mechanical and electronical parts. The first ones were designed with SOLIDWORKS software and printed with a 3D printer using ABS or PLA plastic wires, while the latter were bought in the local market. Figure 3 shows the electronic parts and the device electric wiring diagram.

The device will be monitored by a mobile application. The latter was designed with "App Inventor Designer", which is an online application development tool for Android smartphones and allows anyone to create their own personal application for the Android operating system developed by Google. The development platform is available to all users with a Gmail account. It recalls certain simplified programming languages based on a graphical interface similar to Scratch. Application information is stored on remote servers. They are currently maintained by the Massachusetts Institute of Technology (MIT). The events and control of the UV-C device is depicted in Figure 4.

\section{Results and Discussions}

\subsection{Change in Irradiance over Distance from the Source}

The amount of UV-C radiation that is received in surfaces depends on their locations in the room (i.e. distance from the UV-C emitter) and whether any objects shadow the light. In this study measured different areas of the room to assure that enough UV-C radiation reaches all surfaces. Figure 5 reveals the results of change of UV-C radiation for different distances $(0-300 \mathrm{~cm})$ and heights $(0,30$ and $60 \mathrm{~cm}$ ) from the device.

As reported by Lindblad et al., The farther away the light source, the less the UV-C intensity [10]. The UV-C radiation change over distance follows the inverse square law where the propagation of light intensity decreases exponentially with increasing distance from the light source (see Figure 5).

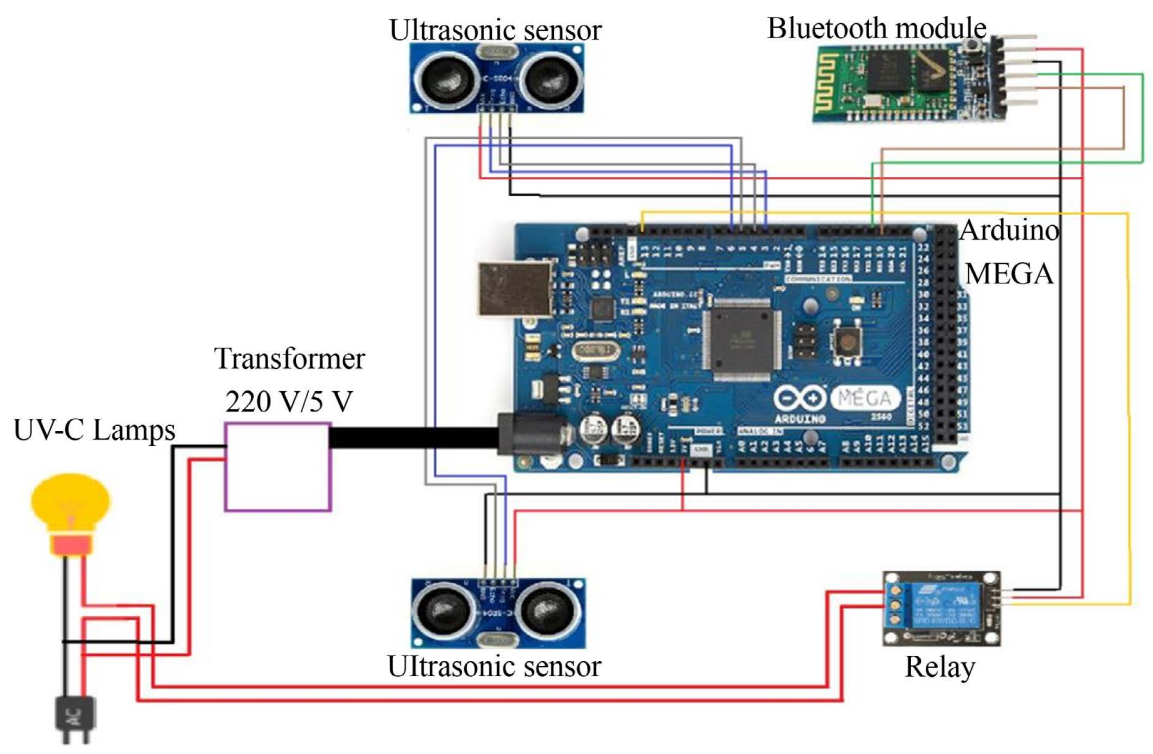

Figure 3. UV-C device electric wiring diagram. 


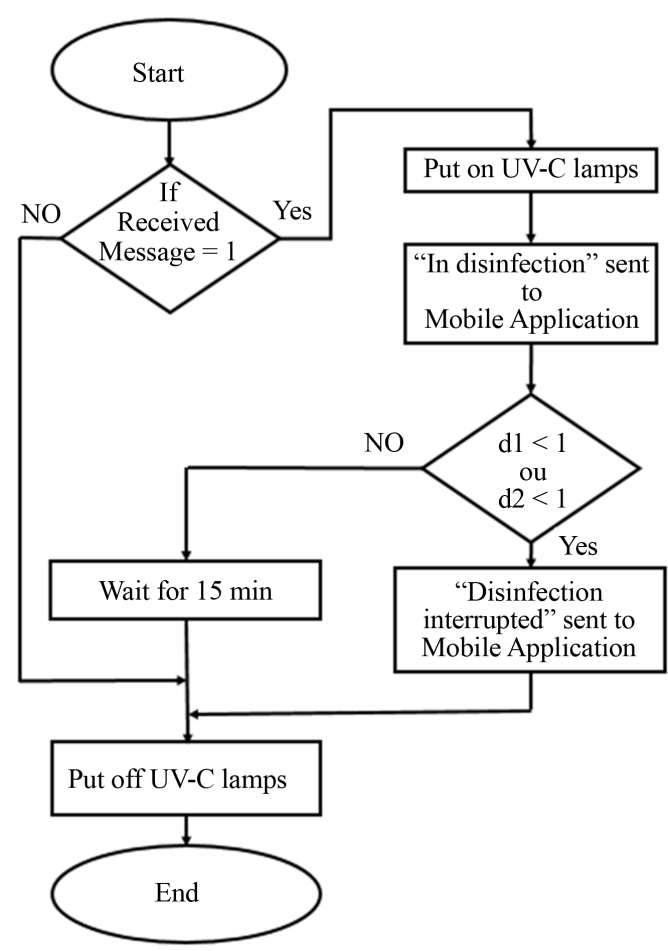

Figure 4. Events and control flowchart of the UV-C device.

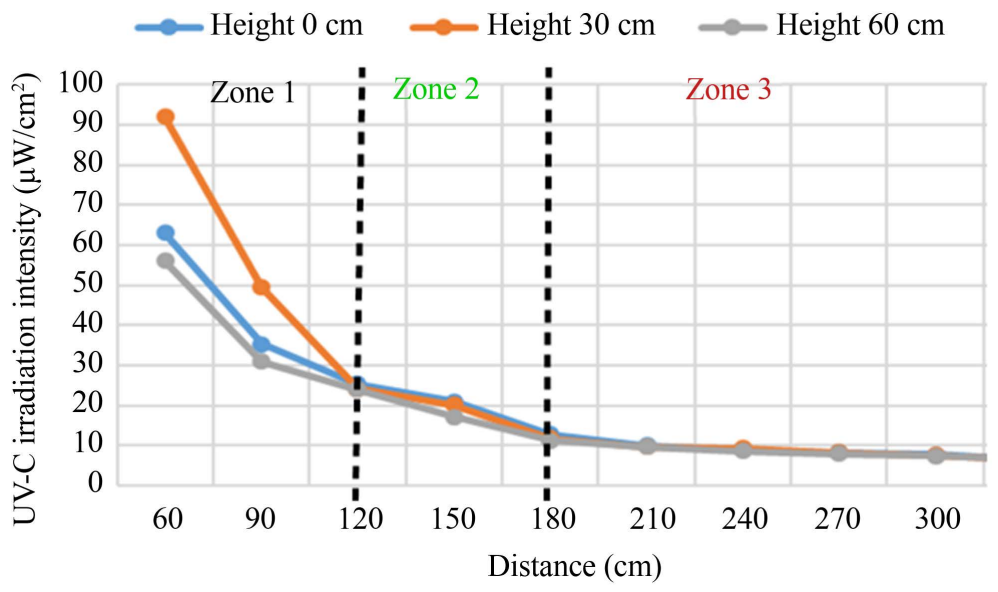

Figure 5. Impact of the distance and the height on UV-C radiation intensity.

About the height three cases were identified. From 0 to $120 \mathrm{~cm}$, the height impacted on the radiation intensity: the closer to the direct line, the higher UV-C intensity (see Figure 5. From 120 to $180 \mathrm{~cm}$ the height slightly impacted the radiation, and above $180 \mathrm{~cm}$, no influence of the height was noticed.

\subsection{Calculated Disinfection Times for Different Nosocomial Pathogens}

The exposure time to achieve $4 \log 10$ (99.99\%) reduction for different nosocomial pathogens were calculated using Equation (1). The results are shown in Table 2. 
Table 2. Exposure time calculated from published UV-C-doses necessary for 4 Log reductions for different microbe.

\begin{tabular}{|c|c|c|}
\hline Pathogen & $\begin{array}{l}\text { UV-C dose } \\
\left(\mathrm{mJ} / \mathrm{cm}^{2}\right)\end{array}$ & $\begin{array}{l}\text { Exposure time } \\
(\min )\end{array}$ \\
\hline \multicolumn{3}{|c|}{ Virus } \\
\hline Poliovirus 1 & $37.0[12]$ & 82.2 \\
\hline Rotavirus SA-11 & $36.0[13]$ & 80.0 \\
\hline$S A R S-C O V-2$ & $5.0[14]$ & 11.1 \\
\hline \multicolumn{3}{|c|}{ Bacteria } \\
\hline Bacillus subtilis ATCC6633 (spore) & $78.0[15]$ & 175.6 \\
\hline Bacillus anthracis (spores) & $97.28[16]$ & 216.2 \\
\hline Campylobacter jejuniATCC 43429 & $4.6[13]$ & 10.2 \\
\hline Citrobacterdiversus & $11.5[17]$ & 25.6 \\
\hline Escherichia coli & $7.0[18]$ & 15.6 \\
\hline Klebsiella pneumoniae & $20.0[17]$ & 44.4 \\
\hline Legionella pneumophila ATCC33152 & $7.7[19]$ & 17.1 \\
\hline Mycobacterium tuberculosis & $24.8[16]$ & 55.1 \\
\hline Pseudomonas aeruginosa & $22.0[16]$ & 48.9 \\
\hline Salmonella enteritidis & $16.0[16]$ & 35.6 \\
\hline Salmonela paratyphi & $12.8[16]$ & 28.4 \\
\hline Salmonella typhosa & $8.6[16]$ & 19.1 \\
\hline Shigella dysenteriae & $6.8[16]$ & 15.1 \\
\hline Shigella sonnei ATCC9290 & $8.2[15]$ & 18.2 \\
\hline Staphylococcus aureus ATCC25923 & $10.4[16]$ & 23.1 \\
\hline Streptococcus faecalis ATCC29212 & $11.2[15]$ & 24.9 \\
\hline Vibrio comma & $13.5[16]$ & 30.0 \\
\hline Yersinia enterocolitica ATCC27729 & $4.6[13]$ & 10.2 \\
\hline \multicolumn{3}{|c|}{ Yeasts } \\
\hline Saccharomyces cerevisiae & $24.0[16]$ & 53.3 \\
\hline Saccharomyces ellipsoideus & $24.0[16]$ & 53.3 \\
\hline \multicolumn{3}{|c|}{ Molds } \\
\hline Aspergillius flavus & $240.0[16]$ & 533.3 \\
\hline Aspergillius niger & $528.0[16]$ & 1173.4 \\
\hline Rhisopus nigricans & $444.0[16]$ & 986.7 \\
\hline \multicolumn{3}{|c|}{ Protozoan } \\
\hline Chlorella Vulgaris & $52.0[16]$ & 115.6 \\
\hline Cryptosporidium parvum & $9.5[20]$ & 21.1 \\
\hline Paramecium & $44.0[16]$ & 97.8 \\
\hline
\end{tabular}




$$
T d=16.667 * \frac{D}{I}
$$

where:

- $\quad T d(\min )=$ disinfection duration in minute;

- $\quad 16.667=$ conversion factor;

- $D\left(\mathrm{~mJ} / \mathrm{cm}^{2}\right)=\mathrm{UV}-\mathrm{C}$ radiation dose to achieve a microbial reduction of 99.99\%, they were taken from ClorDiSys Ultraviolet Light Disinfection Data Sheet Rev. 12 - 2020 [11].

- $I\left(\mathrm{~mW} / \mathrm{cm}^{2}\right)=$ Lowest UV-C irradiation measured in the room.

From these results, it can be seen that the sensitivity to UV-C is not species specific, and any microbe can be eliminated or inactivated by UV-C device if the required expose dose is achieved. In the case of this newly developed UV-C device only four (4) UV-Lamp were installed. We can increase the emitted radiation by installing more lamps, or lamps with higher irradiance to reduce the exposure time needed to disinfect hospital rooms.

\section{Conclusions}

In this paper, a UV-C-based disinfection device was designed and developed in order to fight against nosocomial infections and Covid-19. The device can be monitored from distance by a mobile application using Bluetooth communication in order to avoid contact between users and UV-C radiation known to be dangerous for human health. After the realization of the device, measurements of the radiation intensity of the device are also made, for different distances from the device in a room of $36 \mathrm{~m}^{2}$, and with the lethal doses of the microorganisms found in the literature, exposure time was found by considering the most frequent microorganisms in health structures. Sars-Cov-2 which was the main target could be inactivated within $11 \mathrm{~min}$.

Compared to chemical disinfection, the use of this device is by far the most advantageous. Indeed, this device, in addition to being relatively friendly to environment as the effect of UV radiation disappears as soon as the device is switched off. There is also no direct contact between the operator and the UVs since the control is done remotely.

As the device is stationary, the intensity of the radiation varies greatly with distance. The further treated area is from the device, the less it will be irradiated. The device can therefore be improved by transforming it into a robot, which will make it possible to homogenize the intensity over the entire surface to be disinfected. This will therefore reduce the duration of disinfection. Indeed, in the case where the device is stationary, the duration of disinfection is obtained with the least irradiated area.

Another prospect would also be to test the device in a hospital room to assess its actual effectiveness.

\section{Acknowledgements}

This work was supported by the Ministry of Higher Education, Research and 
Innovation of Senegal Republic through the COVID-19 fund.

\section{Conflicts of Interest}

The authors declare no conflicts of interest regarding the publication of this paper.

\section{References}

[1] World Health Organization (2005) Défi mondial pour la sécurité des patients, 2005-2006: Un soin propre est un soin plus sûr/Alliance mondiale pour la sécurité des patients.

https://apps.who.int/iris/bitstream/handle/10665/43374/9242593737 fre.pdf?sequen $\underline{\mathrm{ce}=1 \text { \&isAllowed }=\mathrm{y}}$

[2] Déguénonvo, L.F., Traoré, K., Dia Badiane, N., Ka, R., Cissoko, Y., Diouf, A., Lakhe, N., Ka, D., Diop, S., Cisse, V., Manga, M., Ndour, C., Soumaré, M., Sow, A. and Seydi, M. (2015) Results of a Survey Incidence of the Cases of Nosocomial Infections with Multidrug Resistant Bacteria in a Hospital Center in Dakar (Senegal). Revue Malienne d' Infectiologie et de Microbiologie, 8, 8-25.

[3] Martinez de Alba, A.E., Rubio, M.B., Morán-Diez, M.E., Bernabéu, C., Hermosa, R. and Monte, E. (2021) Microbiological Evaluation of the Disinfecting Potential of UV-C and UV-C Plus Ozone Generating Robots. Microorganisms, 9, Article No. 172. https://doi.org/10.3390/microorganisms 9010172

[4] Mbaye, M.F., Sarr, N. and Ngom, B. (2021) Construction of Control Charts for Monitoring Various Parameters Related to the Management of the COVID-19 Pandemic. Journal of Biosciences and Medicines, 9, 9-19.

https://doi.org/10.4236/jbm.2021.93002

[5] Ministère de la Santé et de l'Action Sociale (2021) Pandemie Covid 19/Senegal/ Communique 670. https://www.sante.gouv.sn

[6] Falahi, S. and Kenarkoohi, A. (2020) Transmission Routes for SARS-CoV-2 Infection: Review of Evidence. New Microbes and New Infections, 38, Article ID: 100778.

[7] Organisation mondiale de la Santé (2020) Nettoyage et désinfection des surfaces environnementales dans le cadre de la COVID-19: Orientations provisoires, $15 \mathrm{mai}$ 2020. https://apps.who.int/iris/handle/10665/332167

[8] Boyce, J.M., Farrel, P.A., Towle, D., Fekieta, R. and Aniskiewicz, M. (2016) Impact of Room Location on UV-C Irradiance and UV-C Dosage and Antimicrobial Effect Delivered by a Mobile UV-C Light Device. Infection Control \& Hospital Epidemiology, 37, 667-672. https://doi.org/10.1017/ice.2016.35

[9] Mahida, N., Vaughan, N. and Boswell, T. (2013) First UK Evaluation of an Automated Ultraviolet-C Room Decontamination Device $\left(\right.$ Tru- $\left.\mathrm{D}^{\mathrm{mm}}\right)$. The Journal of Hospital Infection, 84, 332-335.

[10] Lindblad, M., Tano, E., Lindahl, C. and Huss, F. (2020) Ultraviolet-C Decontamination of a Hospital Room: Amount of UV Light Needed. Burns, 46, 842-849.

[11] ClorDiSys. Ultraviolet Light Disinfection Data Sheet. https://www.clordisys.com/pdfs/misc/UV\%20Data\%20Sheet.pdf

[12] Thompson, S.S., Jackson, J.L., Suva-Castillo, M., Yanko, W.A., El Jack, Z., Kuo, J., Chen, C.L., Williams, F.P. and Schnurr, D.P. (2003) Detection of Infectious Human Adenoviruses in Tertiary-Treated and Ultraviolet-Disinfected Wastewater. Water Environment Research, 75, 163-170. https://doi.org/10.2175/106143003X140944 
[13] Wilson, B., Roessler, P., Van Dellen, E., Abbaszadegan, M. and Gerba, C. (1992) Coliphage MS-2 as a UV Water Disinfection Efficacy Test Surrogate for Bacterial and Viral Pathogens. Proceedings of American Water Works Association Water Quality Technology Conference, Toronto, 15-19 November 1992, 219-235.

[14] Storm, N., McKay, L.G.A., Downs, S.N., Johnson, R.I., Birru, D., de Samber, M., Willaert, W., Cennini, G. and Griffiths, A. (2020) Rapid and Complete Inactivation of SARS-CoV-2 by Ultraviolet-C Irradiation. Scientific Reports, 10, Article No. 22421.

[15] Chang, J., Osoff, S., Lobe, D., Dorfman, M., Dumais, C., Qualls, R. and Johnson, J. (1985) UV Inactivation of Pathogenic and Indicator Microorganisms. Applied and Environmental Microbiology, 49, 1361-1365.

[16] https://uv-light.co.uk/uv-dosage-required-to-kill-microorganisms/

[17] Giese, N. and Darby, J. (2000) Sensitivity of Microorganisms to Different Wavelengths of UV Light: Implications on Modeling of Medium Pressure UV Systems. Water Research, 34, 4007-4013. https://doi.org/10.1016/S0043-1354(00)00172-X

[18] Sommer, R., Lhotsky, M., Haider, T. and Cabaj, A. (2000) UV Inactivation, Liquid-Holding Recovery, and Photoreactivation of Escherichia coli O157 and Other Pathogenic Escherichia coli Strains in Water. Journal of Food Protection, 63, 1015 1020. https://doi.org/10.4315/0362-028X-63.8.1015

[19] Oguma, K., Katayama, H. and Ohgaki, S. (2004) Photoreactivation of Legionella pneumophila after Inactivation by Low- or Medium-Pressure Ultraviolet Lamp. Water Research, 38, 2757-2763. https://doi.org/10.1016/j.watres.2004.03.024

[20] Craik, S., Weldon, D., Finch, G., Bolton, J. and Belosevic, M. (2001) Inactivation of Cryptosporidium parvum Oocysts Using Medium- and Low-Pressure Ultraviolet Radiation. Water Research, 35, 1387-1398.

https://doi.org/10.1016/S0043-1354(00)00399-7 